This is a self-archived version of an original article. This version may differ from the original in pagination and typographic details.

Author(s): Onkila, Tiina; Mäkelä, Marileena; Järvenpää, Marko

Title: Employee Sensemaking on the Importance of Sustainability Reporting in Sustainability Identity Change

Year: 2018

Version: Accepted version (Final draft)

Copyright: (c) 2017 John Wiley \& Sons, Ltd and ERP Environment.

Rights: In Copyright

Rights url: http://rightsstatements.org/page//nC/1.0/?language=en

Please cite the original version:

Onkila, T., Mäkelä, M., \& Järvenpää, M. (2018). Employee Sensemaking on the Importance of Sustainability Reporting in Sustainability Identity Change. Sustainable Development, 26(3), 217228. https://doi.org/10.1002/sd.1696 


\title{
EMPLOYEE SENSEMAKING ON THE IMPORTANCE OF
}

\section{SUSTAINABILITY REPORTING IN SUSTAINABILITY IDENTITY}

\section{CHANGE}

\begin{abstract}
This study examines employee sensemaking processes in order to understand the role of sustainability reporting in organizational identity change. Through an analysis of 52 interviews with employees in two Finnish companies we develop sensemaking frames for understanding the role of sustainability reporting in organizational identity change. The three sensemaking frames are individualistic, relational and decoupled. Each of these sensemaking frames differs in stakeholder orientation. They indicate that sensemaking influences the interpretation of how important sustainability reporting is for organizational identity change towards sustainability. The study showed how the individualistic and relational frames serve as sensemaking frames for framing sustainability reporting as being possibly beneficial in organizational identity change. However, the decoupled frame highlights the deficiencies of reporting, especially from the perspective of a collectivistic stakeholder orientation. We propose that a better understanding of the decoupled sensemaking frame helps to understand the justifications for the increasing criticism that has been targeted at sustainability reporting.
\end{abstract}

Keywords: employees, organizational identity, sustainability reporting, sensemaking, stakeholder engagement 


\section{INTRODUCTION}

As the debate over the need for sustainability has intensified due to climate change and social problems (Flannery, 2005), business organizations are increasingly expected to make changes for sustainability and to openly inform stakeholders about those changes (Epstein, 2007). However, much doubt has been cast on companies' actions and their desire for genuine and whole-hearted sustainability. Sustainability reporting has become a common way to address the demands for openly informing about sustainability efforts, but it has been criticized as being merely a way to seek legitimacy and maintain 'unsustainability' (Laine, 2005; Gray, 2006; Cho, 2009; Joensuu et al, 2015).

To date, there has been ample research on sustainability reporting in general (Hahn and Kuhnen, 2013). Common research topics deal with regulation, external disclosures, and differing national practices (Parker, 2005). Only a few studies have focused on the internal organizational context, such as those by Adams and McNicholas (2006), Adams and Frost (2008), Adams and Larrinaga-Gonzales (2007) and Järvenpää and Länsiluoto (2016). However, in-depth evidence on the real practices within organizations, such as sensemaking regarding organizational change for sustainability, is lacking. Our study addresses this lack by focusing on the relationship between sustainability reports and an employee's sensemaking of them in order to better understand the gap between sustainability reporting and sustainability change in organizational identity. The study is based on the notion that fundamental organizational changes, such as establishing true sustainability, require changes in organizational identity (Pratt, 2012; Järvenpää and Länsiluoto, 2016). The sensemaking approach allows us to focus on the meanings assigned to sustainability reports and to analyze its relation with the change in organizational identities. Depending on the context, sustainability seems to have a range of meanings for various people (Bebbington, 2001), indicating that there may be several meanings attached to sustainability and sustainability 
reports in organizations. As Weick (1995) suggest, sensemaking is a process by which people give meaning to experience. We especially focus on the organizational identity perspective in sensemaking. For organizational identity, one answers the question: "Who are we as an organization?" (Albert and Whetten, 1985) These aspects of an organization's character are traditionally considered central, distinctive, and enduring (Albert and Whetten, 1985), but later they are also acknowledged as relatively dynamic, fluid, and unstable (Gioia et al.,2000), and as being constituted in the processes of interactions between people (Weick, 1995).

This study asks how employees in a Finnish financial company and a Finnish energy company make sense of sustainability reporting in the change towards a sustainabilityoriented organizational identity. Qualitative, in-depth interviews were conducted with 52 employees in these two organizations and then analyzed by inductive and thematic qualitative analysis. The study identifies sensemaking as a tool for employees to deal with uncertainty and ambiguity related to sustainability reporting. We have developed three sensemaking frames for understanding the role of sustainability reporting in organizational identity change: individualistic, relational, and decoupled. Each of these sensemaking frames differs in their stakeholder orientation.

This article has the following structure. We first review the current research on sustainability reporting and organizational identity change towards sustainability. Second, we present the sensemaking approach applied in this study. We then describe the data and analysis methods and present the results. Finally, we draw conclusions. 
Sustainability reporting has received considerable attention in recent years among academics and practitioners. It has become a much criticized practice, often characterized by the dominance of managerial approaches (Brown and Dillard, 2013; Archel et al., 2011; Brown and Fraser, 2006) and a lack of stakeholder accountability (Brown and Dillard, 2015). The extent to which sustainability reporting serves as a means of contributing to sustainability change has been questioned (Bebbington 2001; Gray, 2006; Adams and Frost 2008; Spence, 2009; Ihlen and Roper, 2014; Järvenpää and Länsiluoto, 2016). Schaltegger et al. (2017) specifies this by saying that companies' reporting does not contribute to sustainable development, because it focuses on specific issues only rather than on the whole.

Prior research has addressed employees as a key stakeholder group for sustainability reporting (Manetti, 2011; Herremans et al., 2015) and sustainability reporting mainly as a tool for internal communication (Hedberg and von Malmborg, 2003; Farneti and Guthrie, 2009; Spence 2009). Growing environmental awareness motivates employees to find out more about their employers' environmental performance (Isenmann and Lenz, 2001; Isenmann, 2007). Employee engagement in the reporting process has also been found to increase the quality of reports (Adams and McNicholas, 2007), and in some cases employee motivation and commitment can improve sustainability performance (Rae et al., 2015). Herremans et al. (2015) expanded on this idea. In their view, employees use sustainability reports to evaluate if their relationship with a company should continue. This finding is supported by studies that stress the congruence between the sustainability values of employees and those of their organizations (Collier and Esteban, 2007). Profound sustainability change includes these value congruencies (Benn and Martin, 2010; Haugh and Talwar 2010). The most profound change towards sustainability requires change in organizational identity (Chen, 2011). Employee participation in sustainability management programs reinforces their experience of corporate identity, which then supports the 
development of sustainability identity. Thus, there is a self-reinforcing loop between organizational identity and sustainability (Chong, 2009).

Reporting seems to be a channel for the top-down management of sustainability in those organizations where managers struggle to communicate their sustainability initiatives to employees (Brunton et al., 2015). A report may serve as a source of greater knowledge on sustainability and could raise the profile of sustainability among employees (Hedberg and von Malmborg, 2003). However, this approach has been questioned from two perspectives. First, as Stubbs et al. (2013) has emphasized, all employees do not seem interested in or even expect a sustainability report or they do not understand its role in sustainability change (Dong et al., 2014). There may also exist tensions and contradiction on how sustainability is perceived and whether it is supported among employees (Humphreys and Brown, 2008; Wright and Nyberg, 2012). Second, top-down management of sustainability has been questioned in recent studies (Onkila, 2015). Therefore, there is little evidence on how sustainability reporting could support the internal change towards sustainable organizational identity. The sensemaking approach helps us to better understand the gap between sustainability reporting and sustainable actions in organizations by focusing on the various meanings given to sustainability reports. Sustainability reporting and practice can thus be decoupled (Meyer and Rowan, 1977). Decoupling is the creation and maintenance of gaps between formal policies and actual organizational practices (Meyer and Rowan 1977). The decoupling between "rules and routines" or "talk and walk" has been examined in, for example, several accounting studies, and these indicate that there can be differences between what should be done and what is actually done, or what is reported as being done and what is actually done (e.g., Lukka 2007; Rautiainen, 2010; Rautiainen and Järvenpää, 2012). This difference is visible even in the reports, as indicated by Dong and Burritt (2010). They found that Australian oil and gas companies report generic issues about their employees but not, for example, the level of employee involvement. 


\section{A SENSEMAKING APPROACH TO SUSTAINABILITY REPORTING}

In sensemaking, people give meaning to an experience (Weick, 1995). Weick (1993, 1995) introduced the concept of sensemaking to organizational studies, providing insight into factors that emerge as organizations address either uncertain or ambiguous situations. Sensemaking theory is situated in socially constructionist approaches to organizations (Weick, 1995) in interpretive paradigm. Sensemaking is thus about how people construct their own reality, about how, through the communication and interaction between the members of an organization, they continuously construct intersubjective realities (Weick, 1995). This approach represents sustainability in organizations as an evolutionary process where many agents act and react upon each other (Nijhof and Jeurissen, 2006).

Sustainability in organizations is an ambiguous concept that creates confusion (Dahlsrud, 2008; Ziek, 2009) and high equivocality (Weick, 1995). Ambiguous situations in organizations lack clarity and consistency, and lead to a search for meaning because of too much or too equivocal information (van der Heijen et al., 2010). The sensemaking approach allows an increase in the understanding of how individuals enact this evolving process. Sensemaking is a process that is used to reduce ambiguity and address uncertainty (Weick, 1995). The ambiguity of sustainability terminology or an overload of information may lead to confusion as well as to a search for meaning (Cramer et al., 2006). Perceived contradictions may also trigger sensemaking (Angus-Leppan et al., 2010), and sustainability may be perceived as contradicting conventional, profit-maximizing business practices (Maitlis and Christensen, 2014).

Basu and Palazzo (2008) linked sensemaking with corporate responsibilities. According to their starting point, sustainability does not result directly from external demands but, instead, 
from organizationally embedded cognitive and linguistic processes. Both Basu and Palazzo's (2008) process model of sensemaking, along with a part of Weick's (1995) original seven properties of sensemaking, stress the importance of identity in sensemaking. Basu and Palazzo's (2008) model identifies three dimensions of the sensemaking process: cognitive (what firms think, including identity orientation and legitimacy), linguistic (what firms say, including justification, and transparency) and conative (how firms tend to behave, including posture, consistency, and commitment). In comparison, Weick (1995) suggests that sensemaking is understood as a process that is grounded in identity construction, retrospective, enactive in sensible environments, social, ongoing, focused on as well as by extracted cues, and driven by plausibility rather than by accuracy. Since Weick's (1995) book, framing has been a central concept in sensemaking. Weick referred to sensemaking as a coherent framework for perception, cognition, action and memory, and he focused on the frames of mind in this meaning. Thus, sensemaking deals with fitting data into a sensemaking frame that is an individual mental model. Our analysis relates the concept of sensemaking frames to individuals' descriptions of organizational identity change.

Identity is a key to understanding modern organizations (Gioia et al., 2000). Identity and identification are central concepts when people, in their context, think about who they are and how it shapes what they enact and how they interpret events. Identity is a collectively held frame within which organizational participants make sense of their world (Weick, 1993, 1995; Currie and Brown, 2003; Thurlow and Mills, 2009). Organizational identity is viewed as those aspects of an organization's character which are central, distinctive, and enduring (Albert and Whetten, 1985). However, Gioia et al. (2000) stated that organizational identity may also be a relatively dynamic, fluid, and unstable concept. Organizational identity can possibly be imputed from expressed values and slogans, but the actual interpretation of these may vary (Gioia, 2000). Identity offers a possibility to understand the relationships between 
self, work, and organization (Alvesson et al., 2008). Organizational identity is increasingly seen as an ongoing process and flow (Gioia and Patvardhan, 2012; Glynn and Watkiss, 2012). Even identities considered coherent and secure may eventually become reshaped, which can lead to a reorientation of organizational reality into new logics of action (Alvesson et al., 2008), such as sustainability.

Basu and Palazzo (2008) highlighted identity orientation as an important dimension in how managers think, discuss and act on sustainability. Based on Brickson (2007), they suggested three types of identity orientation that an organization might adopt: individualistic, relational, and collectivistic. An individualistic orientation emphasizes individual liberty and selfinterest, an organization as separate from others (Brickson 2005, 2007). It focuses on organizational self-interest (Brickson, 2007). Relational orientation emphasizes how organizations are partners in relationships with their stakeholders as well as strong personal ties with identified stakeholders (Brickson, 2005; 2007). It focuses on particular others' benefit (Brickson, 2007). A collectivist orientation emphasizes organizations as members of larger groups beyond the most relevant stakeholders. This type of orientation is almost universal (Brickson, 2005; 2007) and focuses on greater collective welfare. The work of Brickson $(2005,2007)$ on these three identity orientations offers a loose theoretical framework for analyzing sensemaking in organizational identity change towards sustainability.

\section{MATERIAL AND METHODS}

\subsection{Research contexts}

We studied employee sensemaking in two Finnish companies: a financial firm and an energy company. We compare two different contexts of corporate sustainability to create a richer understanding of sensemaking on sustainability reporting. Energy company has a longer 
background with and stronger demands for sustainability, and financial company operates in a business that is more of a newcomer to the field of corporate sustainability due to its smaller environmental impact. However, both companies have a long background in publishing reports, and they are nationally recognized as reporters of organizational sustainability. Nevertheless, the two organizations continue to face evolving sustainability requirements. The energy industry is being met with increasing sustainability demands, but in the financial industry sustainability, as a rather new demand, has yet to be institutionalized. Hill and Levenhagen (1995) have proposed that sensemaking could be used to analyze change in organizational initiatives, but ambiguity related to sustainability has been identified in more advanced organizations as well as in those companies that are just beginning to interpret it (van der Hejden et al., 2010). The studied organizations differ in two crucial aspects: environmental sensitivity and ownership structures. The energy industry is a heavy industry whose operations cause significant environmental impacts whereas the financial sector represents an industry whose environmental impacts are mainly indirect. In addition, the financial firm here is a cooperative and the energy company is privately owned.

The financial firm has a clear goal to be a sustainability pioneer in the Finnish financial industry. It publishes a sustainability report, participates in multiple projects, and some of its employees, including the CEO, are active members of Finnish sustainability networks. Furthermore, because the firm is a cooperative owned by its customers, it must meet special requirements for transparency and responsibility. The organization employs about 3,400 people. The operations cover banking, financing, and insurance services.

In the energy company, sustainability issues are embedded in the corporate strategy. The firm aims at providing sustainable energy solutions and value for stakeholders. It publishes a sustainability report, participates in multiple sustainability projects and some of its employees are active members of, among other groups, Finnish and Swedish sustainability networks. In 
addition, it is listed in several sustainability indexes (e.g., the Dow Jones Sustainability World Index and the Carbon Disclosure Leadership Index). The company employs around 9,000 people, and its operations cover the generation, distribution, and sales of electricity and heat, along with the related expert services.

\subsection{Research material}

This study focuses on how the employees of these two organizations construct meaning and frame the importance of sustainability reporting as an organizational practice for organizational identity change. We therefore adhere to the constructionist and interpretative research approach (Eriksson and Kovalainen, 2008; Weick, 1995). These approaches characterize sensemaking studies (e.g., van der Hejden et al., 2010). The research material consists of 52 qualitative, in-depth interviews with employees in the two organizations. All of the interviews focused on the meaning of sustainability in the organization and covered the same four themes: a job description of the interviewee, views on sustainability in the company, internal sustainability management and communication, and external sustainability management and communication. Sustainability reporting was discussed under the themes of internal and external communication. All the topics were openly discussed from the viewpoint of the employees' daily jobs.

In the financial firm, 27 people were interviewed (for 39-95 minutes each). Employees from all levels of the organizational hierarchy participated: nine managers (e.g., the CEO, heads of finance, $\mathrm{HR}$ and communications), nine experts (e.g., experts from internal services, risk management, and communications), and nine other employees (e.g., employees in customer service and internal services). In the energy company, 25 people were interviewed (for 19-65 minutes each). The interviewees were selected in cooperation with the company representatives. The researchers suggested criteria for interview selection in both companies, 
and the company representatives then named the individuals for the interview. In both companies, we asked to interview employees from different parts of the organization and different levels of the company hierarchy. Another criterion was based on the relation of the individuals to sustainability in the organization. We first asked to interview the employees who had either a full-time or a part-time focus on sustainability issues, and then those employees who had some knowledge or experience of sustainability in the company in different parts of the organization. These individuals were present in the energy company, but the amount of employees in the financial firm who had dealt with sustainability issues was lower, so other employees were also interviewed. People from many levels of the organizational hierarchy participated: nine managers (e.g., the heads of finance, HR, and communications), and sixteen experts (e.g., environmental engineer, EHS manager, manager business development). In contrast to the financial firm, no member of the energy company's top management was interviewed, nor were representatives from the shop-floor level interviewed.

\subsection{Analysis of the interviews}

We approached the data through inductive and thematic qualitative analysis. Our aim was not to reveal one single reality. Instead, we interpreted the multiple meanings constructed in the interviews. The analysis process was supported using Atlas.ti software. The coding process consisted of three rounds. In the first round, all of the interviews were carefully read through and the parts in which sustainability reports were discussed were coded with the general code "reports." We identified interview extracts that were 10 to 20 sentences long with which we continued the analysis process. In the second round, we continued coding the identified sections by initial thematizing based on the meaning given to sustainability reporting and its importance in stakeholder relations. We identified both positive and negative approaches to sustainability reporting, and narrower and wider perspectives to stakeholders. In the third 
round, we integrated the theoretical perspective on organizational identity with our analysis. In particular, we adapted Brickson's (2007) theory of organizational identity and its three identity orientations: individualistic, relational and collectivistic. Based on the empirical data and the theory, the third phase resulted in the final categories. This led us to identify the three frames that were used to make sense of sustainability reporting in organizational identity change: individualistic and relational to enhance its role and decoupled to question its role. Each interviewee used more than one sensemaking frame, often in miscellaneous ways, so the employees themselves cannot be categorized under certain frames.

\section{RESULTS}

\subsection{Individualistic}

In the individualistic frame, employees enacted an identity orientation that emphasizes individual liberty and organizational self-interest (Brickson, 2007). Sustainability reporting was seen as a possibility to construct organizational identity by using terms and phrases such as "opportunity for learning," "internal follow-up," "self-assessment," and "orientation." Organizational self-interest was used to justify the need for sustainability reporting and its existence, and it was seen as the basic motivation for sustainability reporting (cf. Brickson, 2007). The interviewees related sustainability reporting to internal sustainability changes, and the need to learn about its meaning within their organization. Thus, sensemaking arose from the ambiguity of the term sustainability within the organizational context. They viewed the reports as giving them a possibility to analyze their organization and create change towards sustainability. The role of external stakeholders was not stressed, and a view of the organization as distinct from others was constructed (Brickson 2007). The reports were 
furthermore described as "something they wish to be good at" and something "that is taken very seriously in the organization."

In this sense, the importance of sustainability reporting for organizational identity change was positively framed. However, they did not suggest that the sustainability reports actually serve as a tool for organizational identity construction. Instead, the reports were framed as a possibility for such. This type of sensemaking is exemplified in the following comment:

We try to be there where the best practices are developed, and at the same time the thinking here develops. And then when we report, we get to see ourselves a little from another perspective and then the view might live a little. (financial firm)

To this end, a sustainability report was noted as one tool that could support the change. However, this potential was described as a possibility only, and was not based on a current situation. This type of sensemaking was used by the employees in both organizations, but in slightly different meanings. In the energy company, the employees spoke of the need to set internal goals and (measurable) follow-up concerning them, but in the financial organization the employees focused more on the need for learning and changes in value-basis.

\subsection{Relational}

In the relational frame, employees enacted an identity orientation that connects an organization dyadically to particular others. (Brickson, 2007). The orientation was towards external stakeholders. The interviewees related sustainability reporting to the transparency of the firm, meeting external demands and providing support for customer communications, using terms such as "information dissemination" for certain stakeholders and "external showcase of sustainability." The motivation for publishing the report derived from the benefit to other particular others' benefit (Brickson, 2007) and the need to construct identity in interaction with the particular external stakeholders. However, they were not certain who 
should be included in the particular stakeholders, so sensemaking arose from the uncertainty regarding the report's purpose of use and target audiences.

Sustainability reports and their meaning in external relations were framed in a positive manner, but the interviewees did not identify any concrete benefits in external relations from sustainability reporting. Any benefits mentioned were considered to be possible ones only. The interviewees made general references to relations with customers, cooperation partners or other particular stakeholders, but they did not indicate any specific changes in these relations brought about by sustainability reports. Instead, interviewees stated that reports are simply delivered to stakeholders who might be interested in the topic. The following is what a customer service manager responded when asked about the uses of sustainability reports at her company:

Now it's really concrete, something we can give to customers, and we have this report, or rather with this annual report, when we visit some event, it's always with us. Just in case, if the sustainability comes up, and it does come up often, then we can hand it out to the customer. It's a really good tool for us. (financial firm)

For the financial firm, the range of the external stakeholders whom the reports were seen as benefiting included only customers and partners. In contrast, for the energy company a wide variety of stakeholders who could potentially use the reports was named: board of directors, industrial customers, shareholders, investors, consumers, analysts, municipalities, politicians, researchers, authorities, NGOs, and Finnish citizens. However, the usability of the report was, in many cases, expressed only as a possibility, with phrases such as "they possibly use" and "they could use" appearing often.

Relational sensemaking was used by employees in both organizations, but with slightly different meanings. In the energy firm, sustainability reporting was framed as an 
unquestionable and self-evident requirement for doing business, which means that a company aligns its actions to be congruent with the perceived social expectations. Although social expectations were assumed as the basis for the need to report, those expectations were not specified, including where they come from and who actually expects the reporting. Thus, an assumption of "we must report" was constructed without any proper justifications. In the financial firm, the sensemaking was related more strongly to increasing transparency for particular stakeholders than it was to external expectations. The report was produced to be given to particular stakeholders "when necessary" and "if asked".

\subsection{Decoupled}

Within the decoupled frame, employees enacted a discussion of the need for more profound sustainability change within the organizations and society. Thus, they related reporting to creating greater collective welfare (Brickson, 2007), but sensemaking was dominated by decoupling arguments. The interviewees related the decoupling especially with their own, daily tasks and called for more concrete changes. Sustainability reporting was framed as decoupled from organizational identity change towards sustainability. Decoupling was discussed from two perspectives: external and internal.

External decoupling forms a contrast to the relativistic sensemaking frame. Sustainability reporting was described as a useless tool for informing stakeholders about sustainability. Here sensemaking arose from the uncertainty of the reports' purpose and target audiences. The reports were then negatively framed, with the interviewees questioning the need for producing such a report. They found the major problem to be in the structure and content of the reports themselves. Interviewees felt that if the reports were to be used, they should be shorter and easier to read. This type of sensemaking constructs sustainability reporting as 
detached from organizational identity construction because the reports are described as not being used or read by any of the external stakeholders. This type can be seen in the following extract:

This report just isn't reviewed by the authorities because they have their own systems and own perspective. They aren't so interested in sustainable development, just facts and how much pollution is getting to the sea and the air. I think that environmental organizations and such maybe don't, maybe they see it more as, I could imagine, as propaganda...for a large audience or customers, I don't believe they do. It's too distant or too idealistic... (energy company)

Internal decoupling adds that sustainability reporting is being detached from internal sustainability changes. Interviewees openly questioned whether reports are something that actually serve sustainability change in the organization. Sensemaking arose from the ambiguity between what is reported and what sustainability changes are actually implemented within the company. The interviewees took negative positions regarding the sustainability report, saying that reports do not discuss everyday sustainability within the organizations, and are instead something totally separate from it. Instead, the interviewees construct identities for themselves as proponents of greater collective welfare (cf. Brickson, 2007).

It was emphasized that sustainability requires more concrete actions in organizations than publishing a report. Employees stress that something tangible needs to be done throughout the year instead of "a report popping out once a year." Otherwise, sustainability does not become "real" or "personal" through the report, and instead remains on the top level of the organization. The following extract provides an example of this. The interviewee has previously described how sustainability should be more genuine in the organization:

Q: You were just saying that sustainability needs to be a real living thing. So what would that require? 
A: Well, in my opinion it would require some kind of practical measures, that it wouldn't just be a bunch of fancy slides or reports or some other kind of resource. It's a little like we have kind of a double problem, that is, those two words, inside this company, this sustainability and strategy, well they are seen a bit as fancy terms. The regular guy, say a claims manager in the claims department, they don't talk about that stuff. (financial firm)

In the financial firm, only internal decoupling was mentioned. There was the view that employees do not read the reports, do not have time or interest to do so, and that the audience for the report is not considered. In the energy company, both the internal as well as external decoupling were mentioned. The interviewees mentioned multiple stakeholders who do not read the report: authorities, NGOs and customers. In some cases, they felt the reports went unread due to their heaviness, a problem which suggests there is a need to develop clearer shorter and more concise ways of reporting.

Table 1 describes the content of each sensemaking frame, the meaning constructed for sustainability reporting, the basic motivation, its role in organizational identity change and comparison between companies.

\section{DISCUSSION AND CONCLUSIONS}

This study applied a sensemaking approach to investigate employees' perspective on the role of sustainability reporting in organizational identity change. The study developed sensemaking frames for understanding the role based on empirical interview data. These frames are individualistic, relational, and decoupled. These sensemaking frames help us to understand sources for differences in employees' understandings about sustainability reporting and its meaning in internal organizational change towards sustainability. The results 
show that if sustainability reporting is experienced as a positive, it may support organizational identity change towards sustainability. However, negative experiences of reporting mainly lead to criticism of the reports instead of seeing them as possible support for organizational change.

The analysis was partially based on Brickson's (2007) organizational identity orientations. The study showed how individualistic and relational identity orientations serve as sensemaking frames for framing sustainability reporting as possibly beneficial for organizational identity change. However, a collectivistic frame was lacking in these empirical data. Instead, the study created the new decoupled frame. We wish to highlight this frame because it helps to explain the increasing criticism that has been targeted at sustainability reporting (Gray, 2006; Spence, 2009). This frame shows our study's main contribution, namely, the identification of how employees perceive sustainability reports as being detached from their work and, more generally, as not related to real sustainability change in organizations. Previous literature has identified employees as an important stakeholder for sustainability reports in two ways: as demanders of reporting (Huang and Kung, 2010), and as a target audience due to their specific information needs (Spence, 2009). Neither of those roles was identified in this analysis. Instead, the employees seemed to demand more real action than reporting.

This study also provides recommendations for business actors. We encourage managers to reconsider sustainability reporting from the point of view of organizational identity orientation (Brickson, 2007; Albert and Whetten, 1985) and its change towards sustainability (Järvenpää and Länsiluoto, 2016). We encourage them to analyze their reporting practices to determine how the reporting can offer more support for sustainability change (Bebbington 2001; Gray, 2006; Adams and Frost, 2008). Further attention should be given to the content of the reports and to how the reports are communicated to the employees as well as to 
developing genuine interaction and dialogue between management and employees (Brown and Dillard, 2015). In its current form, sustainability reporting is, as such, not a sufficient tool for internal sustainability work. In internal communication, other methods, formats, and media should be developed in order to increase genuine dialogue even though it would use the reports as a source of data. The problem, as we see it, is primarily the content of the reports, not whether reporting is voluntary or obligatory. The content of the reports does not seem to correspond to the daily meanings given to sustainability; therefore, we do not believe that simply making reporting mandatory for each company would change the situation. However, stronger stakeholder engagement during the reporting process might influence the contents of the reports in such a way that both internal and external stakeholders might find them more meaningful, and the reports would correspond better to the meanings that are given to sustainability by at least a majority of the stakeholder representatives. Another option would be to produce different reports for each key (legitimate) stakeholder group, or at least different reports for internal and external stakeholders. Yet such an approach would create a challenge in the resources required. Production of stakeholder-specific reports might eventually turn the focus of sustainability departments completely to reporting instead of keeping them on sustainability improvements within the firm.

The employee interviews showed that sustainability reports are currently targeted mainly at external stakeholders and genuine dialogue between management and employees is limited. For external reporting purposes, the aim in the reports is to represent organizational approaches to sustainability in as favorable a light as possible in order to build a positive sustainable image. Internally, the focus should be more on concrete action instead of on eloquent, image-enhancing words. It seems the current forms of sustainability reporting offer limited support for the construction of organizational identity. However, organizational identities are not simply a result of sustainability policies. Instead, they are constructed more 
in everyday organizational lives and ongoing sensemaking processes and identity work. We propose that if a company is to build an identity as a sustainable organization, the communication with employees should use dialogical channels instead of reporting in a simple stand-alone publication, which often ends up being negatively interpreted and questioned. A dialogical approach would diminish the gap between the sensegiving (meanings provided by those responsible for reporting) and sensemaking (employees' interpretation of the reported information).

To deepen our understanding of the meanings of sustainability reports, we encourage the application of the sensemaking approach with more data sets and in different contexts. In particular, the arguments stakeholders use to criticize reports may offer insights on how reporting practices should be changed and dialogue with employees enhanced (Brown and Dillard, 2015). Dialogue would provide further opportunities for employees to better engage with sustainable actions and the building of genuine sustainable organizational identities. Target audiences are a further important subject for research, including examination of who actually reads the reports and how they interpret the reported information.

\section{Acknowledgments}

We wish to thank Tekes - the Finnish Funding Agency for Technology and Innovation and the Finnish Work Environment Fund for funding our research.

\section{REFERENCES}

Adams CA, Frost GR. 2008. Integrating sustainability reporting into management practices. Accounting Forum 32: 288-302. DOI:10.1016/j.accfor.2008.05.002 
Adams CA, Larrinaga-Gonzales C. 2007. Engaging with organizations in pursuit of improved sustainability accounting and performance. Accounting, Auditing and Accountability Journal 20: 333-355.DOI:10.1108/09513570710748535

Adams CA, McNicholas P. 2006. Making a difference. Sustainability reporting, accountability and organizational change. Accounting, Auditing and Accountability Journal 20: 382-402.DOI:10.1108/09513570710748553

Albert S, Whetten D. 1985. Organizational Identity, in Research in Organizational Behavior Cummings, L.L., Staw, B.M. (eds). California Press: Greenwich; 263-295

Alvesson M, Ashcraft K, Thomas R. 2008. Identity matters: reflections on the construction of identity scholarship in organization studies. Organization 15: 5-28. DOI: $10.1177 / 1350508407084426$

Angus-Leppan T, Metcalf L, Benn S, 2010. Leadership styles and CSR practice: an examination of sensemaking, institutional drivers and CSR leadership. Journal of Business ethics 93: 189-213. DOI: 10.1007/s10551-009-0221-y

Archel P, Husillos J, Spence C. 2011. The institutionalisation of unaccountability: Loading the dice of corporate social responsibility discourse. Accounting, organizations and society 36: 327-343. DOI:10.1016/j.aos.2011.06.003

Basu K, Palazzo G. 2008. Corporate social responsibility: a process model of sensemaking. Academy of management review 33: 122-136. DOI:10.5465/AMR.2008.27745504 
Bebbington J. 2001. Sustainable development: a review of the international development, business and accounting literature. Accounting forum 25: 128-157.

Benn M, Martin A. 2010. Learning and change for sustainability reconsidered: a role for boundary objects. Academy of management learning \& education 9: 397-412.

Brickson S. 2007. Organizational identity orientation: the genesis of the role of the firm and distinct forms of social value. Academy of management review 32: 864-888. DOI: 10.5465/AMR.2007.25275679

Brickson S. 2005. Organizational identity orientation: forging the link between organizational identity and organizations relations with stakeholders. Administrative science quarterly 50: 576-690. DOI:10.2189/asqu.50.4.576

Brown J, Dillard J. 2013. Agonizing over engagement: SEA and the "death of environmentalism" debates. Critical perspectives on accounting 24: 1-18.

Brown J, Dillard J. 2015. Dialogic Accountings for Stakeholders: On Opening Up and Closing Down Participatory Governance. Journal of Management studies 52: 961-985. DOI: 10.1111/joms. 12153

Brown J, Fraser M. 2006. Approaches and perspectives in social and environmental accounting: and overview of the conceptual landscape. Business strategy and the environment 15: 103-117. DOI:10.1002/bse.452 
Brunton M, Eweje G, Taskin N. 2015. Communicating corporate social responsibility to internal stakeholders: walking the walk or just talking the talk. Business strategy and the environment DOI: 10.1002/bse1889.

Chen YS. 2011. Green organizational identity: sources and consequence. Management Decision 49: 384-404. DOI:10.1108/00251741111120761

Cho CH. 2009. Legitimation Strategies Used in Response to Environmental Disaster: A French Case Study of Total SA's Erika and AZF Incidents. European Accounting Review 18: 33-62. DOI:10.1080/09638180802579616

Chong M. 2009. Employee participation in CSR and corporate identity: insights from a disaster-response program in the Asia-Pacific. Corporate reputation review 12: 106-119

Collier J, Esteban R, 2007. Corporate social responsibility and employee commitment. Business ethics: European Review 16: 19-33.

Cramer J, van der Hejden A, Jonker J. 2006. Corporate social responsibility: making sense through thinking and acting. Business ethics: European review 15: 380-389.

Currie G, Brown A. 2003. A narratological approach to understanding processes of organizing in a UK hospital. Human Relations 56: 563-586. DOI: $10.1177 / 0018726703056005003$ 
Dahlsrud A. 2008. How corporate social responsibility is defined: an analysis of 37 definitions. Corporate social responsibility and environmental management 15: 1-13. DOI: $10.1002 /$ csr. 132

Dong S, Burrit R, Qjan W. 2014. Salient stakeholders in corporate social responsibility reporting by Chinese mining and minerals companies. Journal of Cleaner production 84: 5969.

Dong S, Burritt R. 2010. Cross-sectional benchmarking of social and environmental reporting practice in the Australian oil and gas industry. Sustainable Development 18: 108-118. DOI: $10.1002 / \mathrm{sd} .450$

Epstein MJ. 2007. Making sustainability work. Greenleaf Publishing: Sheffield.

Eriksson P, Kovalainen A. 2008. Qualitative methods in business research. Sage: London.

Farneti F, Guthrie J. 2009. Sustainability reporting by Australian public sector organizations: why they report. Accounting Forum 33: 89-98. DOI:10.1016/j.accfor.2009.04.002

Flannery T., 2005. The Weather Makers: The History and Future Impact of Climate Change. Text Publishing: Melbourne.

Gioia DA, Schultz M, Corley KG, 2000. Organizational identity, image and adaptive instability. Academy of management review 25: 63-81. DOI:10.5465/AMR.2000.2791603 
Gioia DA, Patvardhan S. 2012. Identity as Process and Flow. In: Constructing Identity in and around Organizations. Schultz M, Maguire S, Langley A, Tsoukas H. (eds.). Oxford: Oxford University Press.

Glynn, MA, Watkiss L. (2012). Exploring Cultural Mechanisms of Organizational Indentity Construction. In Constructing Identity in and around Organizations. Schultz, M. and Maguire, S. and Langley, A. and Tsoukas, H. (eds.). Oxford: Oxford University Press.

Gray R. 2006. Social, environmental and sustainability reporting and organisational value creation? Whose value? Whose creation? Accounting, Auditing and Accountability journal 19: 793-819. DOI:10.1108/09513570610709872

Hahn M, Kuhnen M. 2013. Determinants of sustainability reporting: a review of results, trends, theory, and opportunities in an expanding field of research. Journal of Cleaner production 59: 5-21.

Haugh N, Talwar A. (2010). How do corporations embed sustainability across the organization? Academy of management learning \& education 9: 384-396.

Hedberg CJ, von Malmborg F. 2003. The global reporting initiative and corporate sustainability reporting in Swedish companies. Corporate social responsibility and environmental management 10: 153-164. DOI: 10.1002/csr.38

Herremans I, Nazari J, Mahmoudian F. 2015. Stakeholder relationships, engagement and sustainability reporting. Journal of Business Ethics DOI: 10.1007/s10551-015-2634-0. 
Hill R, Levenhagen M, 1995. Metaphors and mental models: sensemaking and sensegiving in innovative and entrepreneurial activities. Journal of Management 21: 1057-1074.

Huang C, Kung F, 2010. Drivers of environmental disclosure and stakeholder expectation: Evidence from Taiwan. Journal of Business Ethics 96: 435-451. DOI:10.1007/s10551-0100476-3

Humphreys M, Brown AD. (2008). An analysis of corporate social responsibility at Credit line: a narrative approach. Journal of Business ethics 80: 403-418. DOI: 10.1007/s10551007-9426-0

Ihlen O, Roper J. 2014. Corporate reports on sustainability and sustainable development: we have arrived. Sustainable development 22: 42-51. DOI: 10.1002/sd.524

Isenmann R, Bey C, Welter M. 2007. Online reporting for sustainability issues. Business Strategy and the environment 16: 487-501. DOI:10.1002/bse.597

Isenmann R, Lenz C. 2001.Customized corporate environmental reporting by internet-based push and pull technologies. Eco-management and Auditing 8: 100-110.

Isenmann R. 2007. Information management for sophisticated environmental reporting. In Information Technologies in Environmental Engineering. Gómez, J.M., Sonneschein, M., Müller, M., Welsch, H., Rautenstrauch, C. (eds.),. ITEE 2007 - Third International ICSC Symposium. Environmental Science and Engineering. Springer, Berlin; 69-84. 
Joensuu K, Koskela M, Onkila T. 2015. Social proximity and environmental NGO relationships in corporate sustainability reports. Sustainable development 23: 26-40. DOI: $10.1002 / \mathrm{sd} .1569$

Järvenpää M, Länsiluoto A. 2016. Collective identity, institutional logic and environmental management accounting change. Journal of Accounting \& Organizational Change 12:

152 - 176. DOI 10.1108/JAOC-11-2013-0094

Lukka K. 2007. Management accounting change and stability: Loosely coupled rules and routines in action. Management Accounting Research 18: 76-101.

Maitlis S, Christianson M. 2014. Sensemaking in organization. Academy of Management Annals 8: 57-125. DOI:10.1080/19416520.2014.873177

Manetti G. 2011. The quality of stakeholder engagement in sustainability reporting: empirical evidence and critical points. Corporate social responsibility and environmental management 18: 110-122. DOI:10.1002/csr.255

Meyer JW, Rowan B. 1977. Institutionalized Organizations: Formal Structure as Myth and Ceremony. American Journal of Sociology 83: 340-63.

Nijhof A, Jeurissen R. 2006. Editorial: A sensemaking perspective on corporate social responsibility: introduction to the special issue. Business ethics: European Review 15: 316389. DOI: $10.1111 / \mathrm{j} .1467-8608.2006 .00455 . x$ 
Onkila, T. 2015. Pride or embarrassment? Employee's emotions and corporate social responsibility. Corporate social responsibility and environmental management 22: 222-236. DOI: $10.1002 / \mathrm{csr} .1340$

Orton JD, Weick KE. 1990. Loosely Coupled Systems: A Reconceptualization. Academy of Management Review 15: 203-223.

Parker LD. 2005. Social and environmental accountability research. A view from the commentary box. Accounting, Auditing and Accountability Journal 18: 842-860. DOI $10.1108 / 09513570510627739$

Pratt M G. 2012. Rethinking Identity Construction process in organizations: Three Questions to Consider. In Constructing Identity in and around Organizations. Schultz, M. Maguire, S. Langley, A. Tsoukas, H. (eds.). Oxford: Oxford University Press.

Rae K, Sands J, Gadenne D. 2015. Associations between organizations' motivated workforce and environmental performance. Journal of Accounting and Organizational Change 11: 384405. DOI 10.1108/JAOC-10-2013-0090

Rautiainen AI. (2010). Contending Legitimations: Performance Measurement Coupling and Decoupling in Two Finnish Cities. Accounting, Auditing and Accountability Journal 23: 373-391. DOI 10.1108/09513571011034343 
Rautiainen A,Järvenpää M. 2012. Institutional logics and responses to performance measurement systems. Financial Accountability \& Management 28: 164-188. DOI: 10.1111/j.1468-0408.2012.00541.x

Schaltegger S, Burrit RL. 2000. Contemporary Environmental Accounting - Issues, Concepts and Practice. Greenleaf, Sheffield.

Schaltegger S, Etxeberria IA, Ortas E. 2017. Innovating corporate accounting and reporting for sustainability: Attributes and challenges. Sustainable Development 25: 113-122. DOI: 10.1002/sd.1666.

Spence C. 2009. Social and environmental reporting and the corporate ego. Business strategy and the environment 18: 254-265. DOI:10.1002/bse.600

Stubbs W, Higgins C, Milne M. 2013. Why do companies not produce sustainability reports? Business strategy and the environment 22: 456-470. DOI:10.1002/bse.1756

Thurlow A, Mills J. 2009. Change, talk and sensemaking. Journal of organizational change management 22: 459-579. DOI:10.1108/09534810910983442

Van der Hejden A, Driessen P, Cramer J. 2010. Making sense of corporate social responsibility: exploring organizational processes and strategies. Journal of cleaner production 18: 1787-1796. 
Weick K. 1993. The collapse of sensemaking in organizations: The Mann Gulch disaster. Administrative science quarterly 3: 628-652. DOI:10.2307/2393339

Weick K E. 1995. Sensemaking in Organizations. Sage, London.

Wright C, Nyberg D. 2012. Working with passion: emotionology, corporate environmentalism and climate change. Human relations 65: 1561-1587. DOI: $10.1177 / 0018726712457698$

Ziek P. 2009. Making sense of CSR communication. Corporate social responsibility and environmental management 16: 137-145. DOI:10.1002/csr.183

Table 1. Sensemaking frames on constructed meanings for sustainability reports

\begin{tabular}{|c|c|c|c|c|}
\hline Sensemaking frame & $\begin{array}{l}\text { Meaning of } \\
\text { sustainability reporting }\end{array}$ & Motivation for reporting & $\begin{array}{l}\text { Role in organizational } \\
\text { identity change }\end{array}$ & $\begin{array}{l}\text { Comparison between } \\
\text { companies }\end{array}$ \\
\hline Individualistic & $\begin{array}{l}\text { Internal tool } \\
\text { organization's welfare and } \\
\text { self-enhancement }\end{array}$ & $\begin{array}{l}\text { Organizational self-interest and } \\
\text { willingness to learn }\end{array}$ & $\begin{array}{l}\text { Possibly beneficial - } \\
\text { supports the change by } \\
\text { offering tools for internal } \\
\text { learning }\end{array}$ & $\begin{array}{l}\text { Setting and monitoring } \\
\text { measurable goals (energy } \\
\text { company) versus internal } \\
\text { learning and changes in value } \\
\text { basis (financial company) }\end{array}$ \\
\hline Relational & $\begin{array}{l}\text { External tool }- \text { for } \\
\text { interaction with particular }\end{array}$ & $\begin{array}{l}\text { Particular stakeholders' benefit } \\
\text { and transparency }\end{array}$ & $\begin{array}{lr}\text { Possibly } & \text { beneficial } \\
\text { supports } & \text { sustainability }\end{array}$ & $\begin{array}{l}\text { Self-evident to meet the social } \\
\text { expectations (energy }\end{array}$ \\
\hline
\end{tabular}




\begin{tabular}{|c|c|c|c|c|}
\hline & $\begin{array}{l}\text { stakeholders } \quad \text { and } \\
\text { responding stakeholder } \\
\text { demands }\end{array}$ & & $\begin{array}{l}\text { change by offering tools for } \\
\text { identity negotiations with } \\
\text { stakeholders }\end{array}$ & $\begin{array}{l}\text { company) versus possibly } \\
\text { beneficial for transparency } \\
\text { (financial company) }\end{array}$ \\
\hline Decoupled & $\begin{array}{ll}\text { Not valuable for } \\
\text { organizational identity } \\
\text { change } & \text { towards } \\
\text { sustainability } & \end{array}$ & $\begin{array}{l}\text { Motivation for publishing the } \\
\text { report unclear, not necessary for } \\
\text { internal change (individualistic) } \\
\text { nor in external stakeholder } \\
\text { relations (relational) }\end{array}$ & $\begin{array}{l}\text { Detached from identity } \\
\text { change }\end{array}$ & $\begin{array}{l}\text { Inclusion of external and } \\
\text { internal decoupling (energy } \\
\text { company) versus focus on } \\
\text { internal decoupling (financial } \\
\text { company) }\end{array}$ \\
\hline
\end{tabular}

